\title{
Pengaruh NPF Dan FDR Terhadap CAR Dan Dampaknya Terhadap ROA Pada Perbankan Syariah Di Indonesia
}

\section{Yuwita Ariessa Pravasanti}

Sekolah Tinggi Ilmu Ekonomi AAS, Indonesia

Email korenpondensi: yuwita.akuntansi@gmail.com

\begin{abstract}
Abstrak
Penelitian ini menganalisis tentang NPF dan FDR terhadap CAR dan dampaknya terhadap ROA pada perbankan syariah di Indonesia. Penelitian ini bertujuan untuk mendapatkan bukti empiris mengenai kemungkinan adanya pengaruh Non Performing Financing (NPF) dan Financing to Deposit Ratio (FDR) terhadap Capital Adequacy Ratio (CAR) dan Return On Asset (ROA), serta pengaruh Capital Adequacy Ratio (CAR) terhadap Return On Asset (ROA). Penelitian ini menggunakan analisis data panel dan sampel yang digunakan sebanyak 12 bank syariah dengan laporan keuangan triwulan selama 2 tahun, yaitu 2015-2016 sehingga sampel yang digunakan pada penelitian ini sebanyak 96 data. Hasil penelitian menunjukkan bahwa NPF berpengaruh tidak signifikan terhadap CAR. FDR berpengaruh signifikan terhadap CAR. NPF berpengaruh signifikan terhadap ROA. FDR berpengaruh signifikan terhadap ROA. CAR berpengaruh tidak signifikan terhadap ROA. Hasil Uji F, secara simultan disimpulkan bahwa variabel NPF dan FDR berpengaruh terhadap CAR, dan NPF, FDR, dan CAR berpengaruh terhadap ROA.
\end{abstract}

Kata Kunci: Non Performing Financing (NPF); Financing to Deposit Ratio (FDR); Capital Adequacy Ratio (CAR); Return On Asset (ROA)

\section{Abstract}

This study aims to analyze the NPF and FDR infuence to CAR and impact to ROA of banks on Islamic banking in Indonesia. This study aims to get empirical evidence about the possibility of influence of Non Performing Financing (NPF) and Financing to Deposit Ratio (FDR) to Capital Adequacy Ratio (CAR), and Capital Adequacy Ratio (CAR) to Return on Assets (ROA). This study used panel data analysis and used 12 islamic bank with quarterly financial statement for 2 years, in 2015-2016 so the sample used in this study were 96 data. The data were processed using Microsoft Excel and SPSS 23.The results showed that NPF significant effect on CAR. FDR significant effect on CAR. NPF significant effect on ROA. FDR significant effect on ROA. CAR not significant effect on ROA. The results simultaneously NPF and FDR significant effect on CAR, and NPF, FDR, and CAR significant effect on ROA.

Keywords: Non Performing Financing (NPF); Financing to Deposit Ratio (FDR); Capital Adequacy Ratio (CAR); Return On Asset (ROA).

Saran sitasi: Pravasanti, Y. (2018). Pengaruh NPF dan FDR Terhadap CAR dan Dampaknya Terhadap ROA Pada Perbankan Syariah Di Indonesia. Jurnal Ilmiah Ekonomi Islam, 4(03), 148-159. doi:http://dx.doi.org/10.29040/jiei.v4i03.302

DOI: http://dx.doi.org/10.29040/jiei.v4i03.302 


\section{Pendahuluan}

Undang-Undang No. 21 Tahun 2008 menyatakan bank merupakan badan usaha yang melakukan kegiatan dalam hal menghimpun dana dari masyarakat dalam bentuk simpanan dan menyalurkannya kepada masyarakat dalam bentuk kredit dan atau bentuk-bentuk lainnya dalam rangka meningkatkan taraf hidup rakyat banyak.

Perbankan merupakan lembaga yang memiliki titik yang strategis sentral dalam akumulasi dana masyarakat. Oleh karena itu, perlu adanya prinsip konservatism atau klehatihatian dalam menjaga peran perbankan agar tidak merugikan sistem perekonomian negara. Bank harus dinyatakan sehat agar dapat menjalankan fungsinya dengan baik. Kebutuhan untuk meregulasi bank sebagai institusi bermula dari adanya risiko yang melekat (inherent) pada sistem perbankan. Bank menawarkan sebuah produk yang digunakan oleh setiap nasabah, baik komersial maupun perorangan, yaitu uang.

Soliha \& Taswan (2002) menyatakan bahwa likuiditas dapat juga diartikan sebagai kemampuan manajemen bank dalam menyediakan dana yang cukup untuk memenuhi kewajiban setiap saat. Pengelolaan likuiditas merupakan masalah yang kompleks dalam kegiatan operasional bank. Sulitnya pengelolaan likuiditas tersebut dapat disebabkan karena sebagian besar jumlah dana yang dikelola oleh bank merupakan dana yang berasal dari masyarakat yang sifatnya jangka pendek dan dapat ditarik sewaktu-waktu. Pendapatan suatu bank berasal dari pendapatan bunga atas kredit yang diberikan ke masyarakat. Semakin besar penyaluran dana dalam bentuk kredit dibandingkan dengan deposito (simpanan masyarakat) pada suatu bank, maka konsekuensi semakin besarnya risiko likuiditas yang harus ditanggung oleh bank yang bersangkutan (Syahrir, 2012). Berkembangnya bank syariah di Indonesia ini dapat juga dilihat dari FDR (Financing to Deposit Ratio) nya yang terus meningkat disetiap tahunnya. FDR merupakan salah satu rasio yang dapat digunakan untuk mengukur suatu likuiditas sebuah bank untuk dapat membayar kembali yang dilakukan oleh deposan dengan mengandalkan pembiayaan yang telah diberikan sebagai sumber likuiditasnya.

NPF (Non Perfoming Financing) merupakan rasio yang dapat digunakan untuk mengukur tingkat risiko pembiayaan yang disalurkan oleh perbankan. Rasio NPF membandingkan tingkat risiko pembiayaan yang kurang lancar/ tidak lancar dengan tingkat pembiayaan yang disalurkan oleh pihak perbankan. Rasio NPF mencerminkan tingkat risiko pembiayaan, semakin kecil rasio NPF maka semakin kecil tingkat risiko pembiayaan yang akan ditanggung oleh pihak perbankan, sebaliknya apabila semakin besar tingkat NPF maka semakin besar pula tingkat risiko pembiayaan yang akan ditanggung oleh pihak perbankan.

Kondisi kesehatan sebuah bank dapat dilihat dari laporan keuanganya, apakah terjadi kenaikan ataupun penurunan. Dengan analisis laporan keuangan yang tepat, sebuah bank dapat lebih mengoptimalkan penyusunan rencana strategis ke depannya dalam meminimalisasi risiko keuangan yang dapat terjadi. Untuk itu, sebagai salah satu alat untuk mengukur pemenuhan kewajiban permodalan dapat dihitung dengan menggunakan rasio CAR (Capital Adequacy Ratio) dimana Bank Indonesia menetapkan CAR sebesar 8\% (Ali, 2006). Capital adequacy ratio (CAR) merupakan rasio kecukupan modal dari perbankan dan dapat mempengaruhi tingkat profitabilitas bank syariah. Alasan memilih variabel CAR sebagai variabel independen dikarenakan CAR merupakan indikator yang paling penting menurut Bank Indonesia dalam mengukur kinerja bank. Terdapat pengaruh yang positif antara rasio CAR dengan profitabilitas perbankan (ROA). Hal ini menunjukkan bahwa semakin tinggi CAR maka semakin baik kemampuan bank tersebut untuk menanggung risiko dari setiap aktiva produktif yang berisiko (Wibowo \& Syaichu (2013). Hal berbeda ditunjukkan dari hasil penelitian Suryani (2012) yang diperkuat oleh Guna \& Syaichu (2013) 
yang menunjukkan bahwa CAR tidak berpengaruh terhadap ROA.

Risiko pembiayaan dapat diartikan sebagai risiko yang disebabkan ketidakmampuan nasabah membayar pembiayaan sesuai dengan jadwal angsuran yang sudah ditetapkan. Salah satu cara dalam menilai besar kecilnya risiko pembiayaan yang harus diterima bank syariah adalah melihat dari rasio NPF (Non Performing Financial). NPF seperti halnya NPL (Non Performing Loan) dalam perbankan konvensional. Non Performing Financing (NPF) dapat menunjukkan kemampuan kolektibilitas sebuah bank dalam mengumpulkan kembali kredit yang dikeluarkan oleh bank sampai lunas. Tingkat kesehatan pembiayaan (NPF) ikut mempengaruhi pencapaian laba bank (Suhada, 2009).

Return On asset (ROA) adalah kemampuan suatu perusahaan untuk memperoleh laba yang dinyatakan dalam persentase (Harisman, 2002). Pada usaha perbankan, ROA digunakan untuk mengukur kemampuan manajemen bank dalam memperoleh keuntungan (laba sebelum pajak) yang dihasilkan dari total asset bank yang bersangkutan (SE BI No.6/ 23 /DPNP Jakarta, 31 Mei 2004). Semakin besar ROA suatu bank, semakin besar pula tingkat keuntungan yang dicapai bank tersebut dan semakin baik pula posisi bank tersebut dari sisi asset (Lukman, 2009).

Bank syariah berkembang pesat di negaranegara yang mempunyai penduduk bermayoritas muslim, sepertinya halnya Indonesia, namun seiring berkembangnya Bank Syariah tersebut, terdapat berbagai kendala yang dihadapi dalam tingkat risiko keuangan. Padahal tidak bisa dipungkiri bahwasannya tingkat kesehatan sebuah Bank dinilai apabila dana/modal bank dapat berkembang baik dan memberikan keuntungan yang berarti terhadap perkembangan ekonomi nasional. Berdasarkan penjelasan di atas, tujuan penelitian ini dapat dirumuskan sebagai berikut: 1) Menganalisis pengaruh Non Performing Financing (NPF) terhadap Capital Adequacy Ratio (CAR) dan Return On Asset (ROA), 2) Menganalisis pengaruh Financing
Deposit Ratio (FDR) terhadap Capital Adequacy Ratio (CAR) dan Return On Asset (ROA), dan 3) Menganalisis pengaruh Capital Adequacy Ratio (CAR) terhadap Return On Asset (ROA).

\section{Kajian Pustakan}

\subsection{Non Performing Financing (NPF)}

Risiko Kredit akibat kegagalan setelmen (settlement risk) timbul akibat kegagalan penyerahan kas dan/atau instrumen keuangan pada tanggal penyelesaian (settlement date) yang telah disepakati dari transaksi penjualan dan/atau pembelian instrumen keuangan. Risiko kredit dapat diukur menggunakan rasio Non Performing Financing (NPF). NPF menunjukkan kemampuan manajemen bank dalam mengelola pembiayaan bermasalah yang diberikan oleh bank. Semakin tinggi NPF, maka semakin buruk kualitas kredit bank tersebut. Risiko kredit yang diterima oleh pihak bank diakibatkan adanya ketidakpastian pengembalian kredit yang telah diberikan (Malayu, 2007).

$$
\mathrm{NPF}=\frac{\text { Pembiayaan Bermasalah }}{\text { Total Pembiayaan }} \times 100 \%
$$

\subsection{Financing to Deposit Ratio (FDR)}

Peneliti memilih rasio likuiditas dalam mengukur risiko likuditas, hal ini sesuai dengan penelitian yang dilakukan oleh Yuwono \& \& Sudaryono 2010), penilaian mengenai likuiditas setiap bank berbeda tergantung usaha bank, besarnya bank, dan sebagainya. Oleh karena itu, dalam menilai likuiditas dapat diukur dengan menggunakan rasio Financing to Deposit Ratio (FDR). Rasio ini digunakan untuk mengukur kemampuan sebuah bank dalam membayar hutang jangka pendeknya dan membayar kembali kepada deposannya, serta memenuhi permintaan kredit yang diajukan oleh masyarakat dengan tepat waktu. Angka rasio yang tinggi menunjukkan sebuah bank tidak likuid. FDR merupakan rasio yang membandingkan jumlah pembiayaan yang diberikan dengan simpanan masyarakat.

$$
\text { FDR }=\frac{\text { Pembiayaan }}{\text { Dana Pihak Ketiga }} \times 100 \%
$$




\subsection{Capital Adequacy Ratio (CAR)}

Capital Adequacy Ratio (CAR) adalah rasio kinerja bank untuk mengukur kecukupan modal yang dimiliki bank untuk menunjang aktiva yang mengandung resiko atau menghasilkan risiko, misalkan kredit yang diberikan bank. CAR merupakan rasio yang memperlihatkan seberapa jauh seluruh aktiva bank yang mengandung risiko (kredit, penyertaan, surat berharga, tagihan pada bank lain) ikut dibiayai dari dana modal sendiri bank disamping memperoleh dana-dana dari sumber-sumber di luar bank, seperti dana dari masyarakat, pinjaman, dan lain-lain. (Lukman, 2009) Berdasarkan SE BI Nomor 12/11/DPNP tanggal 31 Maret 2010, rasio CAR (Lukman, 2009) dapat dirumuskan sebagai berikut:

$$
\mathrm{CAR}=\frac{\text { Modal Bank }}{\text { ATMR }} \times 100 \%
$$

CAR merupakan indikator terhadap kemampuan bank untuk menutupi penurunan aktivanya sebagai akibat dari kerugian-kerugian bank yang disebabkan oleh aktiva yang berisiko. CAR ini didasarkan prinsip bahwa setiap penanaman yang mengandung risiko harus disediakan jumlah modal sebesar presentasi terhadap jumlah penanamannya, semakin besar rasio tersebut akan semakin baik posisi modal. Sesuai dengan standar yang telah ditetapkan oleh Bank of International Settlement (BIS) seluruh bank yang ada di Indonesia wajib untuk menyediakan modal minimum sebesar $8 \%$ dari aktiva tertimbang menurut risiko (Kuncoro \& Suhardjono, 2012).

\subsection{Return On Asset (ROA)}

Yuwono \& Sudaryono (2010) menyatakan ROA pada periode tertentu merupakan indikator yang dapat mengukur efektifitas perusahaan dalam menghasilkan laba pada tahun berikutnya. Ini dikarenakan semakin besar ROA, maka semakin efisiensi pengelolaan aktiva sehingga akan meningkatkan laba pada tahun berikutnya. Menurut Bank Indonesia ROA > 1,22\% dinilai sehat, 0,99-1,22\% (cukup sehat), dan $<0,77 \%$ (kurang sehat). Menurut Almilia \& Winny
(2005), ROA merupakan alat ukur untuk menilai kemampuan manajemen Bank dalam mendapatkan keuntungan yang dihasilkan oleh rata-rata total aset Bank tersebut. Berdasarkan SE BI No 3/30/ DPNP tanggal 14 Desember 2001, rumus untuk menghitung ROA adalah:

$$
R O A=\frac{\text { Laba Sebelum Pajak (EBIT) }}{\text { Rata }- \text { rata total Aset }} \times 100 \%
$$

\subsection{Penelitian Terdahulu}

Penelitian ini menganalisis tentang NPF dan FDR terhadap CAR dan dampaknya terhadap ROA pada perbankan syariah di Indonesia. Ismawati (2009) yang menganalisis pengaruh Financing to Deposit Ratio (FDR), Cash Ratio (CR), Capital Adequacy Ratio (CAR), Dan Dana Pihak Ketiga (DPK) Terhadap Tingkat Profitabititas Pada PT Bank Syariah Mandiri Tbk. Penelitian ini menggunakan ROA sebagai pengukur profitabilitas. Penelitian ini menunjukkan bahwa CR, CAR, dan DPK berpengaruh signifikan terhadap ROA sedangkan FDR tidak berpengaruh terhadap ROA.

Akhtar, Ali \& Sadaqat (2011) yang menganalisis faktor yang mempengaruhi kinerja bank islam di pakistan periode 2006-2009. Penelitian ini menggunakan model regresi multivariat dengan hasil rasio pinjaman dan kecukupan modal berpengaruh signifikan terhadap profitabititas, sedangkan manajemen aset tidak berpengaruh terhadap profitabilitas. Ramadan, Kilani \& Kaddumi (2011). yang meneliti sifat hubungan antara profitabilitas dan karakteristik faktor internal dan eksternal bank di Yordania. Hasil dari penelitian ini adalah profitabilitas cenderung terkait dengan kegiatan pinjaman yang tinggi, risiko kredit rendah, dan efisiensi biaya.

Suryani (2012) yang meneliti analisis pengaruh Financing To Deposit (FDR) terhadap Profitabilitas Perbankan Syariah di Indonesia. Hasil dari penelitian ini adalah FDR tidak berpengaruh terhadap ROA. Schiniotakis (2012) yang melakukan penelitian Profitability Factors And Efficiency Of Greek Banks. Jenis Bank, laba Bersih Sebelum pajak, BOPO, Risiko Kredit, 
dan Tingkat Kecukupan Modal sebagai variabel independen dan ROA sebagai variabel dependen. Penelitian ini menyimpulkan bahwa Jenis Bank, Laba bersih sebelum pajak, risiko kredit, BOPO, dan tingkat kecukupan modal berpengaruh terhadap ROA.

Ahmad, Nafees \& Khan (2012) melakukan penelitian Determinants Of Profitability Of Pakistani Banks: Panel Data Evidence For The Period 2001-2010. Penelitian ini menyimpulkan bahwa Biaya, Rasio Modal, dan CKP berpengaruh Signifikan negatif terhadap ROA. Eljelly \& Elobeed (2013) yang meneliti Performance Indicators Of Banks In A Total Islamic Banking System: The Case Of Sudan. Variabel independen dalam penelitian ini adalah Rasio Likuiditas, Cakupan, cakupan Modal, Efisiensi, dan Kontrol. Hasil dari penelitian ini menyimpulkan bahwa keenam indikator memiliki hubungan yang signifikan terhadap ROA.

Hassan, Miniaoui \& Elkelish (2015) yang meneliti Financial Risk And Islamic Banks' Performance In The Gulf Cooperation Council Countries. Hasil penelitian ini menyimpulkan bahwa Risiko Modal dan Risiko Operasional berpengaruh negatif secara signifikan terhadap kinerja (ROA dan ROE). Africano (2016) yang meneliti Pengaruh NPF Terhadap Car Serta Dampaknya Terhadap Profitabilitas Bank Umum Syariah Di Indonesia, menyatakan bahwa NPF berpengaruh negatif terhadap ROA. NPF juga berpengaruh negatif terhadap CAR. CAR berpengaruh negatif terhadap ROA. CAR memediasi parsial pengaruh NPF terhadap ROA.

\subsection{Hipotesis}

H1: Non Performing Financing (NPF) berpengaruh signifikan terhadap Capital Adequacy Ratio (CAR)

H2: Financing Deposit Ratio (FDR) berpengaruh signifikan terhadap Capital Adequacy Ratio (CAR)

H3: Non Performing Financing (NPF) berpengaruh signifikan terhadap Return On Asset (ROA)

H4: Financing Deposit Ratio (FDR) berpengaruh signifikan terhadap Return On Asset (ROA)
H5 : Capital Adequacy Ratio (CAR) berpengaruh signifikan terhadap Return On Asset (ROA)?

\section{Metode Penelitian}

Jenis penelitian ini adalah penelitian kausalitas dengan pendekatan kuantitatif. Penelitian kausalitas adalah desain penelitian yang disusun untuk meneliti kemungkinan adanya hubungan sebab akibat antar variabel (Sanusi, 2014). Sehingga dalam penelitian ini peneliti dapat merumuskan dan menguji hipotesis yang telah dibuat. Adapun pendekatan kuantitatif digunakan untuk meneliti sampel tertentu yang telah memenuhi kriteria sampel penelitian, yaitu dengan menggunakan data sekunder berupa laporan keuangan triwulan dari Bank Syariah yang ada di Indonesia dari tahun 2015- 2016.

Populasi yang digunakan untuk penelitian ini adalah seluruh bank syariah yang ada di Indonesia tahun 2015-2016. Sampel merupakan sebagian dari populasi yang karakteristiknya diselidiki dan dianggap dapat mewakili populasi (Sekaran, 2011). Sampel dalam penelitian ini ditentukan dengan menggunakan metode purposive sampling. Metode pengambilan sampel tersebut menggunakan kriteria sampel yang ditentukan oleh peneliti. Berdasarkan kriteria pengambilan sampel yang ditetapkan, jumlah sampel dalam penelitian ini sebanyak 12 bank syariah di Indonesia dengan kriteria seluruh bank syariah di Indonesia yang sudah menerbitkan laporan keuangan tahun 2015-2016.

Jenis data yang digunakan untuk penelitian ini adalah jenis data kuantitatif, dimana data yang diukur pada penelitian ini merupakan satuan numerik (angka). Data Kuantitaif dalam penelitian ini meliputi Return On Asset, Financing Deposit Ratio, Non Performing Financing, dan Capital Adequacy Ratio. Sumber data yang digunakan dalam penelitian ini diperoleh dari Laporan Keuangan bank Syariah di Indonesia. Metode pengumpulan data pada penelitian ini menggunakan data sekunder (secondary data) yaitu teknik pengumpulan data dari basis data yang diperoleh dari situs situs resmi. 
Variabel penelitian yang digunakan oleh peneliti dalam penelitian ini adalah:

1. Variabel dependen (Y), yaitu variabel yang nilainya dipengaruhi oleh variabel independen. Variabel dependen dalam penelitian ini adalah Return On Asset (ROA), dan Capital Adequacy Ratio (CAR).

2. Variabel Independen (X), yaitu variabel yang menjadi sebab terjadinya atau terpengaruhinya variabel dependen. Variabel independen dalam penelitian ini adalah Financing Deposit Ratio (FDR) dan Non Performing Financing-(NPF)

Ringkasan pengukuran variabel dalam penelitian ini dapat dilihat pada Tabel 1.

Tabel 1. Ringkasan Pengukuran Variabel

\begin{tabular}{clc}
\hline No & Variabel & Pengukuran \\
\hline 1 & ROA & $\frac{\text { EBIT }}{\text { Rata" total Aset }} \times 100 \%$ \\
2 & FDR & $\frac{\text { Pembiayaan }}{\text { DPK }} \times 100 \%$ \\
3 & NPF & $\frac{\text { Pemb.Bermasalah }}{\text { Total Pembiayaan }} \times 100 \%$ \\
6 & CAR & $\frac{\text { Modal Bank }}{\text { ATMR }} \times 100 \%$ \\
\hline
\end{tabular}

Pengolahan data yang dilakukan pada penelitian ini adalah diolah dengan menggunakan software Microsoft Excel dan SPSS ver. 23, dimana data yang diolah berjenis data panel. Data panel menggabungkan jenis data cross section dan data time series.

Metode analisis yang digunakan untuk menguji hipotesis dalam penelitian ini adalah regresi berganda (multiple regression analysis) dengan pendekatan analisis jalur. Untuk menjamin keakuratan data, maka sebelum dilakukan analisis regresi untuk menguji hipotesis dalam penelitian ini, dilakukan terlebih dahulu analisis statistik deskriptif. Selain itu, dilakukan pengujian kelayakan model regresi untuk menilai model regresi. Berikut ini penjelasan terperinci mengenai metode analisis yang dilakukan dalam penelitian ini:

\section{Analisis Statistik Deskriptif}

Statistik deskriptif memberikan gambaran atau deskripsi masing-masing variabel yang dilihat dari nilai rata-rata (mean), standar deviasi, varian, maksimum, minimum, sum, range, kurtosis, dan skewness. Standar deviasi, varian, maksimum, dan minimum menunjukkan hasil analisis terhadap dispersi variabel sedangkan skewness dan kurtosis menunjukkan bagaimana variabel terdistribusi. Varian dan standar deviasi menunjukkan penyimpangan variabel terhadap nilai rata-rata (Ghozali, 2011).

\section{Uji Linieritas}

Uji ini bertujuan untuk mengetahui status linier tidaknya suatu distribusi data penelitian. Hasil yang diperoleh melalui uji linieritas akan menentukan teknis analisis regresi yang akan digunakan. Kriteria pengujian ini dapat dikatakan linier ditolak jika $\chi^{2}$ hitung $>\chi^{2}$ tabel (Ghozali, 2011).

\section{Pengujian Hipotesis Analisis Jalur}

Pengujian ini digunakan untuk menguji hubungan variabel independen dengan variabel dependen yaitu dengan model regresi jalur. Secara umum model dirumuskan sebagai berikut: $\mathrm{Y}_{1}=\alpha+\beta_{1} \mathrm{X}_{1}+\beta_{2} \mathrm{X}_{2}+\mathrm{e}_{1}$

$Y_{2}=\alpha+\beta_{1} X_{1}+\beta_{2} X_{2}+\beta_{3} X_{3}+e_{2}$

Keterangan:

$$
\begin{array}{ll}
\alpha & =\text { Konstanta } \\
\beta_{1}-\beta_{3} & =\text { Koefesien Regresi } \\
\mathrm{Y}_{1} & =\text { CAR } \\
\mathrm{Y}_{2} & =\mathrm{ROA} \\
\mathrm{X}_{1} & =\mathrm{NPF} \\
\mathrm{X}_{2} & =\mathrm{FDR} \\
\mathrm{e} & =\text { Error }
\end{array}
$$

\section{Uji Statistik t}

Menurut Ghozali (2011), uji statistik t pada dasarnya menunjukkan seberapa besar pengaruh variabel independen secara individual dalam menerangkan variasi variabel dependen. Uji $\mathrm{t}$ dalam penelitian ini digunakan untuk menguji signifikansi pengaruh NPF dan FDR terhadap CAR dan ROA, serta CAR terhadap ROA pada perbankan syariah di Indonesia. 


\section{Uji Signifikansi F-test}

Uji statistik $F$ digunakan untuk mengetahui apakah semua variabel independen yang dimasukkan dalam model regresi memiliki pengaruh secara bersama-sama (simultan) terhadap variabel dependen (Ghozali, 2011). Apabila nilai probabilitas signifikansi $<0.05$, maka variabel independen secara bersama-sama mempengaruhi variabel dependen.

\section{Analisis Koefisien Determinasi}

Uji koefisien determinasi pada intinya mengukur seberapa jauh kemampuan model dalam menerangkan variasi variabel dependen (Ghozali, 2011). Nilai koefisien determinasi adalah antara nol dan satu. Nilai $R^{2}$ yang kecil berarti kemampuan variabel-variabel independen dalam menjelaskan variasi variabel dependen amat terbatas.

\section{Hasil dan Pembahasan}

\subsection{Hasil Analisis}

Tabel 2. Hasil Uji Statistik Deskriptif

\begin{tabular}{lrrr}
\hline Variabel & \multicolumn{1}{c}{ Mean } & \multicolumn{1}{c}{$\begin{array}{c}\text { Std. } \\
\text { Deviation }\end{array}$} & N \\
\hline ROA & $-0,1781$ & 4,32601 & 96 \\
NPF & 6,2583 & 7,29950 & 96 \\
FDR & 98,4249 & 22,18881 & 96 \\
CAR & 21,3097 & 10,19051 & 96 \\
\hline
\end{tabular}

Tabel 2, menunjukkan bahwa sampel yang digunakan dalam penelitian ini berjumlah 96 bank syariah. Berdasarkan Tabel dapat diketahui bahwa variabel ROA memiliki nilai rata-rata sebesar -0,18; pada variabel NPF menunjukkan rata-rata sebesar 6,25; Pada variabel financing deposit ratio (FDR) ini menunjukkan bahwa berdasarkan rata-rata Bank Umum Syariah (BUS) masuk dalam kategori yang sehat, hal ini ditandai dengan rata-rata financing deposit ratio (FDR) masih dikisaran 0,98 (Ketentuan Bank Indonesia $85 \%$ sampai dengan $110 \%)$. Pada variabel capital adequacy ratio (CAR) ini menunjukkan bahwa berdasarkan rata-rata Bank Umum Syariah (BUS) masuk dalam kategori yang sehat, hal ini ditandai dengan rata-rata capital adequacy ratio (CAR) masih dikisaran 0,21 (Ketentuan Bank Indonesia $>8 \%$ ).

\section{Hasil Uji Liniearitas}

Tabel 3. Hasil Uji Linieritas

\begin{tabular}{cccr}
\hline Model & $\mathrm{R}$ & R square & $\begin{array}{c}\text { Adjusted R } \\
\text { Square }\end{array}$ \\
\hline 1 & 0,843 & 0,711 & 0,701 \\
\hline
\end{tabular}

Dari hasil uji linieritas menunjukkan nilai $\mathrm{R}^{2}$ sebesar 0,701 dengan jumlah sampel 96, besarnya nilai $\chi^{2}$ hitung $=96 \times 0,843=80,928$ sedangkan nilai $\chi^{2}$ tabel sebesar 119,1 . Nilai $\chi^{2}$ hitung $<\chi^{2}$ tabel jadi dapat disimpulkan bahwa model yang benar adalah model linier.

\subsection{Hasil Analisis Jalur}

\section{Analisis Jalur Persamaan I}

Tabel 4. Hasil Koefesien Persamaan 1

\begin{tabular}{lrrl}
\hline Model & $\begin{array}{r}\text { Standardized } \\
\text { Coefficients }\end{array}$ & $\mathrm{t}$ & $\mathrm{S}$ Sig. \\
\hline NPF & 0,138 & 1,516 & 0,133 \\
FDR & 0,593 & 6,535 & 0,000 \\
\hline
\end{tabular}

a. Dependent Variable: CAR

$$
\mathrm{Y}_{1}=0,138 \mathrm{X}_{1}+0,593 \mathrm{X}_{2}
$$

Keterangan:

$$
\begin{aligned}
& \mathrm{Y}_{1}=\text { Capital Adequacy Ratio }(\mathrm{CAR}) \\
& \mathrm{X}_{1}=\text { Non Performing Financing }(\mathrm{NPF}) \\
& \mathrm{X}_{2}=\text { Financing Deposit Ratio }(\mathrm{FDR})
\end{aligned}
$$

Non Performing Financing memiliki nilai $\beta_{1}$ $=0,138$ menunjukkan bahwa NPF tidak berpengaruh signifikan terhadap CAR. Hal ini dapat dinyatakan dalam model regresi bahwa setiap kenaikan NPF, maka akan meningkatkan CAR sebesar variabel pengaliannya yaitu sebesar 0,138 .

Financing Deposit Ratio memiliki nilai $\beta_{2}=$ 0,593 menunjukkan bahwa FDR berpengaruh signifikan terhadap CAR. Hal ini dapat dinyatakan dalam model regresi bahwa setiap kenaikan FDR, maka akan meningkatkan CAR sebesar variabel pengaliannya yaitu sebesar 0.593.

\section{Analisis Jalur Persamaan II}

Tabel 5. Hasil Koefesien Persamaan 2

\begin{tabular}{cccc}
\hline Model & $\begin{array}{c}\text { Standardized } \\
\text { Coefficients }\end{array}$ & $\mathrm{t}$ & Sig. \\
\hline (Constant) & & & \\
NPF & $-0,682$ & $-10,102$ & 0,000 \\
FDR & $-0,333$ & $-4,128$ & 0,000 \\
CAR & 0,117 & 1,539 & 0,127 \\
\hline
\end{tabular}

a. Dependent Variable: ROA 


$$
Y_{2}=-0.682 X_{1}-0.333 X_{2}+0.117 X_{3}
$$

Keterangan:

$\mathrm{Y}_{2}=$ Ratio On Asset (ROA)

$\mathrm{X}_{1}=$ Non Performing Financing (NPF)

$\mathrm{X}_{2}=$ Financing Deposit Ratio (FDR)

$\mathrm{X}_{3}=$ Capital Adequacy Ratio (CAR)

Non Performing Financing memiliki nilai $\beta_{1}$ $=-0,682$ menunjukkan bahwa NPF berpengaruh signifikan terhadap ROA. Hal ini dapat dinyatakan dalam model regresi bahwa setiap kenaikan NPF, maka akan mengurangi ROA sebesar variabel pengaliannya yaitu sebesar 0,682 .

Financing Deposit Ratio memiliki nilai $\beta_{2}=$ -0,333 menunjukkan bahwa FDR berpengaruh signifikan terhadap ROA. Hal ini dapat dinyatakan dalam model regresi bahwa setiap kenaikan FDR, maka akan mengurangi ROA sebesar variabel pengaliannya yaitu sebesar -0,333.

Capital Adequacy Ratio memiliki nilai $\beta_{3}=$ 0,117 menunjukkan bahwa CAR berpengaruh tidak signifikan terhadap ROA. Hal ini dapat dinyatakan dalam model regresi bahwa setiap kenaikan CAR, maka akan menambah ROA sebesar variabel pengaliannya yaitu sebesar 0,117 ,

\section{Uji t}

Tabel 6. Hasil Uji t

\begin{tabular}{cccl}
\hline $\begin{array}{c}\text { Analisis } \\
\text { Jalur }\end{array}$ & Variabel & Sig. & Keterangan \\
\hline Persamaan & NPF & 0,133 & $\mathrm{H}_{1}:$ \\
I & FDR & 0,000 & $\begin{array}{l}\text { Diterima } \\
\mathrm{H}_{2} \text { Ditolak }\end{array}$ \\
\hline Persamaan & $\mathrm{NPF}$ & 0,000 & $\mathrm{H}_{3}$ : Ditolak \\
II & FDR & 0,000 & $\mathrm{H}_{4}$ : Ditolak \\
& CAR & 0,127 & $\mathrm{H}_{5}$ : Diterima \\
\hline
\end{tabular}

Pengaruh Non Performing Financing (NPF) terhadap Capital Adequacy Ratio (CAR), menunjukkan bahwa $\mathrm{H}_{1}$ diterima yang berarti bahwa NPF berpengaruh tidak signifikan terhadap CAR, dimana hasil pengujiaannya menunjukkan bahwa 0,133>0,05.

Pengaruh Financing Deposit Ratio (FDR) terhadap Capital Adequacy Ratio (CAR), menunjukkan bahwa $\mathrm{H}_{2}$ ditolak yang berarti bahwa NPF berpengaruh signifikan terhadap
CAR, dimana hasil pengujiaannya menunjukkan bahwa $0,000<0,05$.

Pengaruh Non Performing Financing (NPF) terhadap Ratio On Asset (ROA), menunjukkan bahwa $\mathrm{H}_{3}$ ditolak yang berarti bahwa NPF berpengaruh signifikan terhadap ROA, dimana hasil pengujiaannya menunjukkan bahwa $0,000<$ 0,05 .

Pengaruh Financing Deposit Ratio (FDR) terhadap Ratio On Asset (ROA), menunjukkan bahwa $\mathrm{H}_{4}$ ditolak yang berarti bahwa NPF berpengaruh signifikan terhadap ROA, dimana hasil pengujiaannya menunjukkan bahwa $0,000<$ 0,05 .

Pengaruh Capital Adequacy Ratio (CAR) ) terhadap Ratio On Asset (ROA), menunjukkan bahwa $\mathrm{H}_{5}$ diterima yang berarti bahwa CAR berpengaruh tidak signifikan terhadap ROA, dimana hasil pengujiaannya menunjukkan bahwa $0,000<0,05$.

\section{Uji F}

\section{Hasil Uji F Persamaan I}

Tabel 7. Hasil Uji F Persamaan I

\begin{tabular}{cccccc}
\hline Model & $\begin{array}{l}\text { Sum of } \\
\text { Squares }\end{array}$ & Df & $\begin{array}{l}\text { Mean } \\
\text { Square }\end{array}$ & f & Sig. \\
\hline Regression & 4528,355 & 2 & 2264,178 & 39,454 & $0,000^{\mathrm{b}}$ \\
\hline
\end{tabular}

a. Dependent Variable: CAR

b. Predictors: (Constant), FDR, NPF

Hasil uji fit data pada Tabel. 5 diperoleh nilai F hitung sebesar 39,45 serta nilai probabilitas sebesar 0,000 . Hasil perbandingan menunjukkan bahwa nilai probabilitas $(0,000)<$ $(0,05)$, sehingga persamaan I memenuhi kriteria fit. Hasil dari Tabel 7 disimpulkan bahwa variabel NPF dan FDR berpengaruh terhadap CAR.

\section{Hasil Uji F Persamaan II}

Tabel 8. Hasil Uji F Persamaan II

\begin{tabular}{ccrccc}
\hline Model & $\begin{array}{c}\text { Sum of } \\
\text { Squares }\end{array}$ & Df & $\begin{array}{c}\text { Mean } \\
\text { Square }\end{array}$ & f & Sig. \\
\hline Regression & 1263,408 & 3 & 421,136 & 75.312 & $.000^{\mathrm{b}}$ \\
\hline
\end{tabular}

a. Dependent Variable: ROA

b. Predictors: (Constant), CAR, NPF, FDR

Hasil uji fit data pada Tabel 8 diperoleh nilai F hitung sebesar 75,312 serta nilai probabilitas sebesar 0,000. Hasil perbandingan menunjukkan 
bahwa nilai probabilitas $(0,000)<(0,05)$, sehingga persamaan II memenuhi kriteria fit. Hasil dari Tabel 8, disimpulkan bahwa variabel NPF, FDR, dan CAR berpengaruh terhadap ROA.

\section{Koefesien Determinasi $\left(\mathbf{R}^{\mathbf{2}}\right)$}

Tabel 9. Koefesien Determinasi $\left(\mathrm{R}^{2}\right)$

\begin{tabular}{ccc}
\hline & $\begin{array}{c}\text { Nilai R } \\
\text { Square }\end{array}$ & $\begin{array}{c}\text { Nilai Adjusted } \\
\text { R Square }\end{array}$ \\
\hline Uji Model I & .459 & .447 \\
Uji Model II & .711 & .701 \\
\hline
\end{tabular}

Berdasarkan Tabel 9 dapat diketahui nilai dari $\mathrm{R}^{2}$ total dengan cara sebagai berikut:

1) Menghitung $e_{1}$ pada persamaan struktural $I$ dengan cara $e_{1}=\sqrt{ } 1-R=\sqrt{ } 1-0.447=$ 0.743

2) Menghitung $e_{2}$ pada persamaan struktural II dengan cara $e_{2}=\sqrt{ } 1-R=\sqrt{ } 1-0.701=$ 0.546

3) Total $\mathrm{R}^{2}=1-\left\{\left(\mathrm{e}_{1}^{2}\right) \times\left(\mathrm{e}_{2}^{2}\right)\right\}=1-\left\{\left(0.743^{2}\right)\right.$ $\left.\mathrm{x}\left(0.701^{2}\right)\right\}=1-\{0.552 \times 0.491\}=0.729$

Perhitungan diatas menunjukkan untuk total $\mathrm{R}^{2}$ pada model yang digunakan adalah 0.729 atau $72.9 \%$ artinya bahwa model persamaan ini, yaitu variabel independen terdiri dari NPF, FDR, CAR memiliki kontribusi pengaruh sebesar $72,9 \%$ terhadap ROA.

\subsection{Pembahasan}

\section{Pengaruh NPF terhadap CAR}

Hasil menunjukkan bahwa NPF tidak berpengaruh signifikan terhadap CAR, hal ini disebabkan karena pembiayaan bermasalah tidak mempengaruhi jumlah pendapatan yang akan diterima oleh bank, sehingga bank akan menggunakan modal yang ada untuk membiayai kegiatan operasionalnya. Semakin sering terjadi kemacetan akan menyebabkan kerugian pada bank yang bersangkutan, kerugian itu memaksa bank menutup kebutuhan modalnya dari modal sendiri, kemudian akan menurunkan rasio kecukupan modal bank.

\section{Pengaruh FDR terhadap CAR}

Hasil menunjukkan bahwa FDR berpengaruh signifikan positif terhadap CAR, hal ini disebabkan karena rasio FDR yang tinggi mengindikasikan jumlah pembiayaan yang diberikan oleh bank syariah kepada masyarakat lebih besar. Semakin besar pembiayaan yang diberikan bank syariah kepada nasabah, akan meningkatkan keuntungan bank tersebut. Keuntungan bank syariah tersebut akan dialokasikan pada modal, sehingga semakin besar pembiayaan maka modal yang diperoleh juga semakin meningkat. Hasil ini sejalan dengan penelitian yang telah dilakukan oleh Oktaviana \& Syaichu (2016) yang menyatakan bahwa FDR memiliki pengaruh positif signifikan terhadap CAR.

\section{Pengaruh NPF terhadap ROA}

Hasil menunjukkan bahwa NPF berpengaruh signifikan negatif terhadap ROA, Hal ini menunjukkan bahwa semakin besar NPF akan berdampak pada penurunan Profitabilitas. NPF yaitu rasio yang digunakan untuk mengetahui pembiayaan yang bermasalah terkait dengan kemungkinan bahwa pada saat jatuh tempo debitur dana gagal memenuhi kewajibannya terhadap bank. Sehingga perlu adanya kehatihatian pihak bank dalam menjalankan fungsinya. Risiko berupa kesulitan pengembalian pembiayaan oleh debitur dengan jumlah yang cukup besar dapat mempengaruhi kinerja bank. Terdapatnya pembiayaan bermasalah tersebut menyebabkan pembiayaan yang disalurkan banyak yang tidak memberikan hasil. Tingginya NPF juga mengakibatkan munculnya pencadangan yang lebih besar, sehingga pada akhirnya modal bank menjadi berkurang. Besarnya NPF menjadi salah satu penghambat tersalurnya pembiayaan perbankan. Peningkatan pembiayaan bermasalah ini menimbulkan pembentukan cadangan pembiayaan bermasalah ini menjadi semakin besar. Kerugian pembiayaan merupakan biaya yang berarti menurunkan laba. Tingginya nilai NPF dapat berdampak pada kesehatan bank. Semakin besar NPF maka semakin besar pula kerugian yang dialami bank, 
yang kemudian akan mengakibatkan berkurangnya keuntungan bank. Keuntungan yang berkurang akan mengakibatkan total asset bank tersebut juga ikut berkurang. Hasil penelitian ini konsisten dengan hasil penelitian Nugroho \& Pangestuti (2011); Almunawwaroh \& Marliana (2017) menyatakan bahwa NPF berpengaruh negatif signifikan terhadap ROA.

\section{Pengaruh FDR terhadap ROA}

Hasil menunjukkan bahwa FDR berpengaruh signifikan negatif terhadap ROA, dimana Finacing to Debt Ratio (FDR) menyatakan seberapa jauh kemampuan bank dalam membayar kembali penarikan dana yang dilakukan deposan dengan mengandalkan pembiayaan yang diberikan sebagai sumber likuiditasnya. Semakin besar pembiayaan maka pendapatan yang diperoleh naik. Dalam kegiatan operasional, bank dapat mengalami kelebihan atau kekurangan likuiditas. Apabila terjadi kelebihan, maka hal itu dianggap sebagai keuntungan bank. Sedang apabila terjadi kekurangan likuiditas, maka bank memerlukan sarana untuk menutupi kekurangan tersebut. Likuiditas yang rendah menunjukkan bahwa bank lebih banyak menempatkan dananya pada Bank Indonesia, pada bank lain atau dalam bentuk surat berharga. Rendahnya likuiditas berdampak pada ekspansi pembiayaan. Hal ini dilakukan karena bank mempertimbangkan resiko pinjaman sehingga berdampak pada rendahnya rentabilitas bank syariah. Pada penelitian ini, FDR berpengaruh signifikan negatif terhadap ROA, hal ini dapat dijelaskan bahwa peningkatan jumlah pinjaman yang diberikan tidak selalu sejalan dengan peningkatan laba sebelum pajak, bahkan ada kecenderungan sebaliknya yaitu peningkatan jumlah pinjaman diikuti dengan penurunan laba sebelum pajak karena jumlah pinjaman tersebut lebih banyak dikonversi dalam bentuk asset bank. Sehingga dapat disimpulkan bahwa secara parsial rasio FDR berpengaruh negatif signifikan terhadap ROA. Hal ini sejalan dengan penelitian yang telah dilakukan oleh Wibisono \& Wahyuni (2017); Lemiyana \& Litriani (2016) yang menyatakan bahwa FDR berpengaruh signifikan secara negatif terhadap ROA.

\section{Pengaruh CAR terhadap ROA}

Hasil menunjukkan bahwa CAR berpengaruh tidak signifikan terhadap ROA, dimana CAR merupakan indikator terhadap kemampuan bank untuk menutupi penurunan aktivanya sebagai akibat dari kerugian-kerugian bank yang disebabkan oleh aktiva yang berisiko. CAR ini didasarkan prinsip bahwa setiap penanaman yang mengandung risiko harus disediakan jumlah modal sebesar presentasi terhadap jumlah penanamannya, semakin besar rasio tersebut akan semakin baik posisi modal. Sesuai dengan standar yang telah ditetapkan oleh Bank of International Settlement (BIS) seluruh bank yang ada di Indonesia wajib untuk menyediakan modal minimum sebesar $8 \%$ dari aktiva tertimbang menurut risiko (Kuncoro \& Suhardjono, 2012). CAR tidak berpengaruh terhadap ROA. Hal ini disebabkan karena bank syariah yang beroperasi tidak mengoptimalkan modal yang ada. Hasil penelitian ini didukung oleh Harun (2016) yang menunjukkan bahwa CAR tidak berpengaruh terhadap ROA.

\section{Kesimpulan}

Penelitian ini menganalisis tentang NPF dan FDR terhadap CAR dan dampaknya terhadap ROA pada perbankan syariah di Indonesia. Penelitian ini bertujuan untuk mendapatkan bukti empiris mengenai kemungkinan adanya pengaruh Non Performing Financing (NPF) dan Financing to Deposit Ratio (FDR) terhadap Capital Adequacy Ratio (CAR) dan Return On Asset (ROA), serta pengaruh Capital Adequacy Ratio (CAR) terhadap Return On Asset (ROA). Berdasarkan hasil analisis menunjukkan bahwa: Non Performing Financing (NPF) berpengaruh tidak signifikan terhadap Capital Adequacy Ratio (CAR) dan Return On Asset (ROA); Financing Deposit Ratio (FDR) berpengaruh signifikan terhadap Capital Adequacy Ratio (CAR) dan Return On Asset (ROA); dan Capital Adequacy Ratio (CAR) berpengaruh tidak signifikan 
terhadap Ratio On Asset (ROA). Hasil uji fit F disimpulkan bahwa variabel NPF dan FDR berpengaruh terhadap CAR, dan persamaan II yaitu variabel NPF, FDR, dan CAR berpengaruh terhadap ROA.

\section{Ucapan Terimakasih}

Penulis mengucapkan terimakasih terhadap seluruh pihak yang sudah memberikan dukungan serta doa sehingga penulis dapat menyelesaikan peneitian ini, khususnya kepada LPPM STIE AAS yang sudah membantu dan mendukung hingga terselesainya penelitian ini.

\section{Daftar Pustaka}

Africano, F. (2016). Pengaruh NPF terhadap CAR serta Dampaknya terhadap Profitabilitas Bank Umum Syariah di Indonesia. Jurnal Ilmiah STIE MDP, 6(1).

Ahmad, S., Nafees, B., \& Khan, Z. A. (2012). Determinants of profitability of Pakistani banks: Panel data evidence for the period 2001-2010. Journal of Business Studies Quarterly, 4(1), 149.

Akhtar, M. F., Ali, K., \& Sadaqat, S. (2011). Factors influencing the profitability of Islamic banks of Pakistan. International Research Journal of Finance and Economics, 66(66), 1-8.

Ali, M. (2006). Manajemen Risiko: Strategi perbankan dan Dunia Usaha menghadapi tantangan globalisasi bisnis. RajaGrafindo Persada.

Almilia \& Herdiningtyas, W. (2005). Analisis Rasio CAMEL terhadap Prediksi Kondisi Bermasalah pada Lembaga Perbankan Periode 2000-2002. Jurnal akuntansi dan Keuangan, 7(2).

Almunawwaroh, M., \& Marliana, R. (2018). Pengaruh CAR, NPF dan FDR Terhadap Profitabilitas Bank Syariah Di IndonesiA. AMWALUNA, 2(1), 1-17.

Eljelly, A. M., \& Elobeed, A.A. (2013). Performance indicators of banks in a total Islamic banking system: the case of Sudan. International Journal of Islamic and Middle Eastern Finance and Management, 6(2), 142-155.
Ghozali, I. (2011). Analisis Multivariate Program IBM SPSS 19. Semarang: Badan Penerbit Universitas Diponogoro.

Guna, R. P., \& Syaichu, M. (2013). Analisis Faktor-Faktor Yang Mempengaruhi Profitabilitas Perbankan (Studi Kasus pada Bank Umum Milik Negara (Persero) yang Terdaftar di Bank Indonesia Tahun 20062011)(Doctoral dissertation, Fakultas Ekonomika dan Bisnis).

Harisman (2002). Tugas Bank Indonesia dama Pengawasan dan Pembinaan Perbankan Syari'ah di Indonesia. Jurnal Hukum Bisnis, 20.

Harun, U. (2016). Pengaruh Ratio-ratio Keuangan Car, Ldr, Nim, Bopo, Npl Terhadap Roa. Jurnal Riset Bisnis dan Manajemen, 4(1), 67-82.

Hassan Al-Tamimi, H., Miniaoui, H., \& Elkelish, W. (2015). Financial Risk and Islamic Banks Performance in the Gulf Cooperation Council Countries. The International Journal of Business and Finance Research, 9(5), 103-112.

Ismawati, D. (2009). Pengaruh Financing to Deposit Ratio (FDR), Cash Ratio (CR), Capital Adequacy Ratio (CAR), dan Dana Pihak Ketiga Terhadap Tingkat Profitabilitas PT. Bank Mandiri Syariah, TBK Periode 2006-2008.

Kuncoro, M. \& Suhardjono, (2012). Manajemen Perbankan: Teori dan Aplikasi, Edisi Kedua, Fakultas Ekonomi dan Bisnis UGM.

Lemiyana, L. L., \& Litriani, E. E. (2016). Pengaruh NPF, FDR, BOPO Terhadap Return On Asset (ROA) Pada Bank Umum Syariah. I-ECONOMICS: A Research Journal on Islamic Economics, 2(1), 31-49.

Lukman, D. (2009). Manajemen Perbankan. Jakarta: Ghalia Indonesia.

Malayu, H. (2007). Manajemen sumber daya manusia. Bumi Aksara. Jakarta.

Nugroho, E., \& Pangestuti, I. R. D. (2011). Analisis Pengaruh Likuiditas, Pertumbuhan Penjualan, Perputaran Modal Kerja, Ukuran Perusahaan dan Leverage terhadap Profitabilitas Perusahaan (Studi pada Perusahaan Manufaktur yang Terdaftar 
pada BEI pada Tahun 2005-2009) (Doctoral dissertation, Universitas Diponegoro).

Oktaviana, R., \& Syaichu, M. (2016). Analisis Pengaruh Size, Roa, Fdr, Npf Dan Bopo Terhadap Capital Adequacy Ratio Pada Bank Umum Syariah Di Indonesia Periode Tahun 2010-2014 (Doctoral dissertation, Fakultas Ekonomika dan Bisnis).

Ramadan, I. Z., Kilani, Q. A., \& Kaddumi, T. A. (2011). Determinants Of Bank Profitability: Evidance From Jordan. International Journal of Academic Research, 3(4).

Sanusi, A. (2014). Metode Penelitian Bisnis, Cetakan Keempat. Jakarta: Salemba Empat.

Schiniotakis, N.I. (2012). Profitability factors and efficiency of Greek banks. EuroMed Journal of Business, 7(2), 185-200.

Sekaran, U. (2011). Research Methods for business Edisi I and 2. Jakarta: Salemba Empat.

Soliha, E. \& Taswan, (2002). Pengaruh Kebijakan Hutang Terhadap Nilai Perusahaan Serta Beberapa Faktor Yang Mempengaruhinya. Jurnal Bisnis dan Ekonomi, 9(2), 149-163.

Suhada, M. (2009). Modul Short Course Bank Syariah. Yogyakarta: STEI.
Suryani, S. (2012). Analisis Pengaruh Financing To Deposit Ratio (FDR) Terhadap Profitabilitas Perbankansyariah Di Indonesia (Rasio Keuangan pada BUS dan UUS Periode 2008-2010). Economica: Jurnal Ekonomi Islam, 2(2), 153-170.

Syahrir, A. A. (2012). Analisis Pengaruh LDR, NPL, dan CAR terhadap Resiko Likui-ditas pada Bank Pembangunan Daerah (BPD) SeIndonesia Tahun 2007-2011. Fakultas Ekonomi dan Bisnis Universitas Hasanuddin Makassar, dipublikasikan.

Wibisono, M. Y., \& Wahyuni, S. (2017). Pengaruh CAR, NPF, BOPO, FDR, terhadap ROA yang Dimediasi oleh NOM. Jurnal Bisnis dan Manajemen, 17(1), 41-62.

Wibowo, E. S., \& Syaichu, M. (2013). Analisis Pengaruh Suku Bunga, Inflasi, CAR, BOPO, NPF Terhadap Profitabilitas Bank Syariah. Diponegoro Journal of Management, 2(2), 10-19.

Yuwono, W., \& Sudaryono, E. (2010). Analisis Capital, Asset Quality, Earning, dan Liquidity Sebagai Alat Untuk Memprediksi Kinerja Keuangan Bank Perkreditan Rakyat. Jurnal Bisnis dan Manajemen, 10(1), 81-90. 